\title{
PELATIHAN TAI CHI DAN PELATIHAN AI CHI SAMA-SAMA MENINGKATKAN PERFORMA DUAL TASK PADA LANSIA
}

\author{
Andy Sirada ${ }^{1}$, I Putu Gede Adiatmika ${ }^{2}$, Muhammad Ali Imron ${ }^{3}$, \\ I Putu Adiartha Griadi ${ }^{2}$, I Made Muliarta ${ }^{2}$, Putu Astawa ${ }^{4}$ \\ ${ }^{1}$ Program Studi Magister Fisiologi Keolahragaan Universitas Udayana, Denpasar \\ ${ }^{2}$ Departemen Ilmu Faal, Fakultas Kedokteran Universitas Udayana, Denpasar \\ ${ }^{3}$ Fakultas Fisioterapi Universitas 'Aisyiyah, Yogyakarta \\ ${ }^{4}$ Departemen Orthopedi dan Traumatologi, RSUP Sanglah, Denpasar
}

E-Mail: andysirada@gmail.com

\begin{abstract}
ABSTRAK
Pendahuluan: Aktifitas yang dilakukan seseorang dalam kesehariannya tidak lepas dari aktifitas multitasking dimana pada aktifitas tersebut minimal seseorang harus mampu melakukan dua aktifitas sekaligus (dualtask), lansia dengan gangguan kognitif atau tidak mampu melakukan aktifitas ganda atau dualtask mempunyai resiko jatuh yang tinggi. Salah satu tindakan untuk meningkatkan kemampuan kognitif dan dualtask pada lansia adalah dengan latihan Tai Chi. Tai Chi dan $A i C h i$ merupakan dua metode latihan yang terbukti mampu meningkatkan kualitas hidup lansia dimana mengurangi resiko jatuh salah satunya. Tujuan penelitian untuk membuktikan apakah ada perbedaan pelatihan Tai Chi dan pelatihan $A i$ Chi dalam meningkatkan performa dual task pada lansia.

Metode: Penelitian dilakukan selama 6 minggu di Rumah Sakit Umum Daerah Kota Mataram Lombok dimana sampel penelitian adalah pasien poliklinik fisioterapi yang berusia 60-80 tahun. Penelitian menggunakan rancangan two group pre and post test design dengan jumlah sampel 34 orang yang terbagi menjadi 2 kelompok yaitu Kelompok Ai Chi $(\mathrm{n}=17)$ dan Kelompok Tai Chi $(\mathrm{n}$ =17). Performa dual task diukur menggunakan time up and go test (TUG) dual task.

Hasil: Nilai performa dualtask pelatihan Tai Chi dan pelatihan Ai Chi meningkat bermakna dengan nilai p $<0,05$. Nilai performa dual task setelah pelatihan Tai Chi dan pelatihan Ai Chi tidak berbeda bermakna dengan nilai performa dual task $\mathrm{p}>0,05$.

Simpulan: Pelatihan Tai Chi dan Pelatihan Ai Chi mempunyai efek yang sama dalam meningkatkan performa dual task pada lansia.
\end{abstract}

Kata kunci: Dual Task, Risiko Jatuh, Lansia, Ai Chi, Tai Chi, Aquatic Therapy.

\section{TAI CHI TRAINING AND AI CHI TRAINING ARE EQUIVALENT IN IMPROVING DUAL TASK PERFORMANCE IN ELDERLY}

\begin{abstract}
Background: Activities carried out by someone in their daily life are inseparable from multitasking activities where at least one person must be able to do two activities at once (dualtask), the elderly with cognitive impairment or unable to do multiple activities or dualtask have a high risk of falling. One of the treatment to improve cognitive abilities and dualtasks in the elderly is to practice Tai
\end{abstract}


Chi. Tai Chi and Ai Chi are two training methods that are proven to improve the quality of life of the elderly, which reduces the risk of falling is one of its benefit. The purpose of this research is to prove whether there are differences in Tai Chi training and Ai Chi training in improving dual task performance in the elderly.

Method: The study was conducted for 6 weeks at the General Hospital Mataram City in Lombok where the study sample was patients in physiotherapy polyclinic aged 60-80 years. The study used a two group pre and post test design with a sample size of 34 people divided into 2 groups: the Ai Chi group $(n=17)$ and the Tai Chi group $(n=17)$. Dual task performance is measured using a dual time up and go test (TUG)

Results: The value of dualtask performance of Tai Chi training and Ai Chi training increased significantly in this study with a value of $p<0.05$. Dual task performance after Tai Chi training and Ai Chi training did not differ significantly from the performance value of dual task $p>0.05$.

Conclusions: Tai Chi Training and Ai Chi Training have the same effect in improving dual task performance in the elderly.

Keywords: Dual Task, Risk Fall, Older Adult, Ai Chi, Tai Chi, Aquatic Therapy.

\section{PENDAHULUAN}

Salah satu problem lansia adalah jatuh, dalam beberapa penelitian bahwa risiko jatuh juga terkait dengan fungsi kognitif. Metode untuk mendefinisikan gangguan kognisi dan tipe kejadian jatuh keduanya penting ketika menganalisis resiko jatuh. Pengukuran secara global terhadap kognisi dikaitkan erat dengan kejadian jatuh yang berdampak cedera, meskipun tidak ada perhitungan yang jelas pada ambang nilainya. Fungsi eksekutif juga dikaitkan dengan peningkatan resiko jatuh yang mana membantu menprediksi resiko jatuh terutama ketika pemeriksaan global dalam batas normal ${ }^{1}$.

Salah satu indikator jatuh terkait terutama fungsi eksekutif dan kemampuan untuk berjalan sambil melakukan tugas lain, yaitu, dual task ${ }^{2}$. Berjalan setiap hari di lingkungan yang kompleks yang memerlukan perencanaan, pemindaian, negosiasi multi-tasking dan hambatan $^{3}$. Berdasarkan gagasan ini, sejumlah peneliti telah menyarankan bahwa tes pola berjalan sementara subjek melakukan tugas ganda/ dual task lainnya mungkin juga efektif dalam memprediksi risiko jatuh ${ }^{4}$.

Fungsi eksekutif adalah istilah umum untuk proses kognitif yang mengatur, mengontrol, dan mengelola proses kognitif lainnya seperti perencanaan, kerja memori, atensi, penyelesaian masalah, penalaran verbal, penghambatan, fleksibilitas mental, pengalihan tugas, inisiasi dan pemantauan tindakan ${ }^{5}$.

Fungsi eksekutif semakin dianggap penting sebagai komponen kunci dari keseimbangan dan kontrol postural ${ }^{6}$. Peningkatan dalam domain fungsi kognitif ini dapat memainkan peran dalam memediasi efek Tai Chi dan $\mathrm{Ai}$ Chi pada keseimbangan dan kontrol motorik. Kaitan antara peningkatan fungsi eksekutif dan kontrol motorik yang terkait dengan Tai Chi didukung oleh beberapa penelitian terkait komponen kognitif pada resiko jatuh ${ }^{7}$.

Pemilihan program pelatihan Tai Chi (TC) dan pelatihan $\mathrm{Ai} C h i$ (AC) tentu saja dapat menjadi solusi alternatif dan jalan keluar dalam menurunkan resiko jatuh terkait fungsi eksekutif terutama kognitif gerak tugas ganda/ dual task. Mekanisme yang mungkin membantu adalah termasuk peningkatan keseimbangan, caregiving, kontrol postural, sensitivitas proprioseptif, dan pengurangan rasa takut jatuh $^{8}$. Subjek yang dilatih dalam pelatihan TC serta $\mathrm{AC}$ juga memberikan peningkatan reaksi vestibular pada tes sensorial selama perubahan postural dan akurasi proprioseptif yang lebih besar jika dibandingkan dengan kelompok kontrol $^{9}$. 


\section{METODE PENELITIAN}

Penelitian ini menggunakan two group pre and post test design. Untuk mengetahui makna $\mathrm{Ai} C \mathrm{Chi}$ terhadap peningkatan performa dualtask pada lansia dibandingkan dengan pemberian Tai Chi di darat. Subjek penelitian dibagi dua kelompok, Kelompok I adalah subjek yang mendapatkan perlakuan berupa Ta $i$ chi, sedangkan Kelompok II adalah subjek yang mendapatkan perlakuan berupa $\mathrm{Ai} C h i$.

Penelitian ini dilakukan di Rumah Sakit Umum Daerah Kota Mataram Lombok NTB. untuk perlakuan pelatihan $\mathrm{Ai} C h i$ dan Tai Chi pada pukul 08.00 - sampai selesai dilaksanakan di Rumah Sakit Umum Daerah Kota Mataram Lombok NTB.

Tiap Kelompok diberikan program latihan dengan durasi 30-60 menit selama tiga kali sepekan. Responden yang terlibat dalam penelitian ini berusia 60 hingga 80 tahun, pria dan wanita, dengan nilai Mini Mental State Examination (MMSE) 17-23 probable cognitive impairment (PCI). Performa dual task diukur dengan Dual Task Time Up and Go (TUG) Test.

\section{HASIL PENELITIAN}

\section{Karakteristik Subjek Penelitian}

Tabel 1.

\begin{tabular}{|c|c|c|c|c|c|c|}
\hline & \multicolumn{3}{|c|}{$\begin{array}{l}\text { Kelompok I } \\
\quad(\mathrm{n}=17)\end{array}$} & \multicolumn{3}{|c|}{$\begin{array}{l}\text { Kelompok II } \\
\quad(\mathrm{n}=17)\end{array}$} \\
\hline & $\mathrm{N}$ & $\%$ & Mean \pm SD & $\mathrm{N}$ & $\%$ & Mean \pm SD \\
\hline \multicolumn{7}{|l|}{ Jenis } \\
\hline \multicolumn{7}{|l|}{ Kelamin } \\
\hline \multicolumn{7}{|l|}{ Laki-laki } \\
\hline & 7 & 41,18 & & 10 & 58,82 & \\
\hline Perempuan & 10 & 58,82 & & 7 & 41,18 & \\
\hline Usia & & & $71,47 \pm 6,12$ & & & $70,27 \pm 4,74$ \\
\hline
\end{tabular}

Dari Tabel1 jumlah total keseluruhan responden, sebanyak $50 \%$ adalah perempuan atau berjumlah 17 orang. Sedangkan sisanya sebesar $50 \%$ atau berjumlah 17 orang adalah laki-laki. Rata-rata usia responden adalah 70,85 $\pm 5,42$ tahun. Dengan masing masing kelompok berjumlah 17 orang dengan usia rata-rata untuk

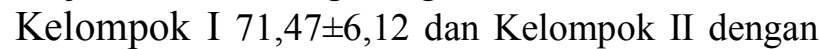
rata-rata usia $70,27 \pm 4,74$. Tingkat Pendidikan responden adalah 10 orang responden adalah lulusan sekolah dasar/rakyat atau 29,4\%, lulusan sekolah menengah pertama ada 11 orang atau $32,4 \%$, lulusan sekolah menengah atas 8 orang yaitu $23,5 \%$, dan sisanya adalah lulusan perguruan tinggi 5 orang atau $14,7 \%$. Semua responden adalah pasien dengan keluhan nyeri punggung bawah dengan VAS (Visiual Analog Scale) di bawah 5

\section{Uji Normalitas dan Homogenitas}

Tabel 2.

\begin{tabular}{|c|c|c|c|}
\hline \multirow{3}{*}{ Kelompok } & \multicolumn{2}{|c|}{ Kolmogorov-Smirnov Test } & Levene's Test \\
\hline & \multicolumn{2}{|c|}{ p-value } & \multirow{2}{*}{$p$-value } \\
\hline & Kelompok I & Kelompok II & \\
\hline \multicolumn{4}{|l|}{ Pre } \\
\hline \multirow{2}{*}{$\begin{array}{l}\text { Dualtask } \\
\text { Post } \\
\quad \text { Dualtask }\end{array}$} & 0,200 & 0,200 & 0,364 \\
\hline & 0,200 & 0,200 & 0,607 \\
\hline \multicolumn{4}{|c|}{$\begin{array}{l}\text { *Shapiro Wilk Test } \\
*^{* *} \text { Levene's Test }^{* * *}\end{array}$} \\
\hline Pada & Table & menur & pada \\
\hline
\end{tabular}
Kelompok I dan Kelompok II sebelum dan setelah perlakuan menunjukkan nilai $p>0,05$ yang berarti data berdistribusi normal. Hasil dari uji homogenitas pada data sebelum perlakuan Kelompok I dan Kelompok II menunjukkan nilai $\mathrm{p}>0,05$ yang berarti data homogen

\section{Hasil Uji Beda Nilai TUG Kelompok Tai Chi dan Kelompok $\mathrm{Ai}$ Chi}

Tabel 3.

\begin{tabular}{|c|c|c|c|}
\hline \multirow[t]{2}{*}{ Intervensi } & \multicolumn{2}{|c|}{$\begin{array}{c}\text { Mean } \pm \text { SD } \\
(\text { detik })\end{array}$} & \multirow[b]{2}{*}{$p$} \\
\hline & Tai chi & $A i$ chi & \\
\hline \multicolumn{4}{|l|}{ Pre } \\
\hline \multicolumn{4}{|l|}{ Dualtask } \\
\hline & $9,64 \pm 0,54$ & $9,88 \pm 0,82$ & 0,314 \\
\hline \multicolumn{4}{|l|}{ Post } \\
\hline Dualtask & $8,65 \pm 0,64$ & $8,86 \pm 0,78$ & 0,394 \\
\hline
\end{tabular}


Berdasarkan hasil analisis yang tersaji pada Tabel 3 di atas, didapat post dualtask nilai $\mathrm{p}=$ 0,394 dimana nilai $\mathrm{p}>0,05$ yang artinya Ho diterima dan Ha ditolak. Hasil ini menunjukkan bahwa tidak ada perbedaan yang signifikan antara pelatihan Tai Chi dan pelatihan $\mathrm{Ai} C h i$ terhadap peningkatan performa dualtask pada lansia

\section{PEMBAHASAN}

\section{Pelatihan Tai Chi Dapat Meningkatkan Performa Dual Task}

Dari hasil analisis penelitian yang dilakukan dengan durasi 30-60 menit/hari menunjukkan bahwa pelatihan Tai Chi terbukti dapat meningkatkan performa dual task.

Secara konseptual, diperkirakan bahwa setidaknya ada enam elemen terapi yang berpotensi melekat dalam pelatihan Tai Chi yang mungkin mendasari dampaknya pada fungsi kognitif $^{10}$. Pertama, latihan aerobik sedang, dengan metabolik ekivalen diperkirakan antara 1,5 dan 4.0. Intensitas aerobik ini telah terbukti memiliki efek positif pada fungsi kognitif ${ }^{11}$. Penting bahwa, dampak olahraga didukung oleh penelitian mengaitkan perubahan fungsional dengan perubahan neurofisiologis seperti peningkatan faktor neurotropik otak dan plastisitas dalam morfologi dan fungsi otak, termasuk proses sentral ke fungsi eksekutif ${ }^{12}$.

Ke dua, melatih kelincahan dan mobilitas, yang oleh beberapa bukti menunjukkan dampak fungsi kognitif jalur neurofisiologis yang unik untuk mereka yang terkait dengan latihan aerobik. Satu studi melaporkan bahwa kebugaran aerobik dan otot ke duanya terkait dengan fungsi eksekutif, dimana kebugaran motorik (kelincahan dan mobilitas) dikaitkan dengan kontrol eksekutif dan kecepatan perseptual. Sejalan dengan perubahan fungsional ini adalah pola aktivasi yang berbeda dinilai menggunakan fMRI selama Flanker tes ${ }^{13}$.

Ke tiga, melibatkan pembelajaran dan menghafal keterampilan dan pola gerakan baru; studi pembelajaran berbasis keterampilan lainnya seperti kegiatan-kegiatan termasuk tari, juggling, dan musik telah menunjukkan peningkatan kognitif fungsi dan mekanisme saraf $^{14}$. Misalnya, juggling pembelajaran telah dilakukan terkait dengan peningkatan materi abu-abu di korteks occipito-temporal ${ }^{15}$ dan pelatihan dansa dengan formasi hippocampal ${ }^{16}$. Pemahaman yang lebih baik tentang cara belajar rutinitas Tai Chi yang bervariasi dalam kompleksitas koreografi berdampak pada struktur dan fungsi otak akan sangat meningkatkan pemahaman mekanistik kita tentang Tai Chi pada fungsi kognitif.

Ke empat, merupakan pelatihan dalam fokus pada atensi berkelanjutan, pengalihan, dan multi-tugas yang dapat membantu melatih memori kerja, pembagian perhatian, fleksibilitas kognitif, dan keseluruhan fungsi eksekutif. Satu studi yang menggunakan paradigma visual dan point-point yang terkomputerisasi melaporkan bahwa dibandingkan dengan kontrol Tai Chi amatir yang setara usianya, praktisi Tai Chi yang mahir telah meningkatkan koordinasi tanganmata dan waktu gerakan selama tugas yang melibatkan kognitif pemrosesan ${ }^{17}$.

Ke lima, pelatihan meditasi dan relaksasi Tai Chi telah terbukti mengurangi kecemasan dan depresi ${ }^{18}$ yang dapat memengaruhi kortisol dan stres terkait lainnya. jalur penurunan kognitif $^{19}$. Relevansi komponen Tai Chi ini didukung oleh studi yang mengaitkan pelatihan meditasi dengan peningkatan dalam banyak fungsi dan aspek neurofisiologis kinerja kognitif ${ }^{20}$.

Akhirnya, waktu yang lebih banyak dialokasikan untuk kegiatan rekreasi dan dukungan sosial telah dikaitkan dengan peningkatan fungsi kognitif ${ }^{21}$. Singkatnya, enam elemen terapi yang saling tergantung di Tai Chi ini mungkin memberikan efektivitas yang lebih besar dalam meningkatkan fungsi kognitif, dibandingkan dengan unimodal intervensi yang menargetkan serangkaian mekanisme dan jalur fisiologis yang lebih terbatas. 


\section{Pelatihan $\mathrm{Ai}$ Chi Dapat Meningkatan Performa Dual Task}

Kognitif dapat meningkat bila seseorang melakukan aktivitas fisik secara teratur. Aktivitas fisik langsung dapat menstimulasi otak dan meningkatkan protein di otak yang disebut Brain Derived Neurotrophic Factor (BDNF). Protein BDNF ini berperan penting menjaga sel saraf tetap bugar dan sehat serta berperan terhadap fungsi memori pada otak. Kadar BDNF yang rendah dapat menyebabkan penurunan daya hantar antar saraf sehingga gerak menjadi lambat. Semakin banyak lansia melakukan aktivitas fisik akan mengaktifkan peningkatan protein BDNF pada otak sehingga daya hantar saraf mengalami peningkatan dan akan meningkatkan waktu reaksi, kognitif dan reflek yang akan mempengaruhi keseimbangan $^{22}$.

Salah satu latihan yang aman dan efektif adalah di air yaitu salah satu metodenya adalah Ai Chi dimana gerakannya yang lambat dan santai terutama pada gerakan kaki dan badan (bagian dari Tai Chi) dan polanya yang mengalir dan nafas dalam ( bagian dari $q i$ gong), media air seperti "cushion" dimana menurunkan beban tumpuan tubuh sementara disisilain memberikan resistensi terhadap gerakan lansia saat latihan, latihan di air juga meningkatkan keseimbangan dan menurunkan nyeri ${ }^{23}$.

Lingkungan dimana seseorang tinggal mempunyai dampak yang besar dalam mempertahankan dan meningkatkan fungsi eksekutif $^{24}$. Dalam lingkungan air dimana tubuh menerima perbedaan stimulus terutama perbedaan gravitasi dan tekanan air sangat penting untuk tetap mempertahankan posisi tubuh dalam air termasuk keseimbangan dinamis. Setiap individu yang masuk ke dalam air terkonfrontasi secara unik oleh perubahan adaptasi tubuh terhadap kontraksi otot, kewaspadaan somatis dan juga konsentrasi untuk mempertahankan posisi tubuh pada postur latihan yang benar. Latihan bias jadi dibuat ringan dengan menambahkan grounding forces (efek dari gravitasi) dari menambahkan pemberat pada pergelangan kakinya atau memberikan waktu untuk tubuh menyesuaikan diri dengan berlatih di kedalaman air yang lebih dangkal dimana gravitasi masih mendominasi tekanan melampaui daya apung air. Secara konsekuen, efek dapat secara bertahap ditingkatkan untuk stimulasi yang lebih banyak dari lingkungan air yaitu seperti meningkatkan koordinasi, konsentrasi, serta variasi kebutuhan latihan kognitif dimana dapat meningkatkan hasil performa kognitif ${ }^{24}$.

\section{Pelatihan Tai Chi dan Pelatihan $\mathrm{Ai}$ Chi Sama-sama Meningkatkan Performa Dual Task}

Dari hasil penelitian didapatkan hasil bahwa kedua pelatihan yaitu Tai Chi dan $A i$ Chi dapat meningkatkan performa dual task pada lansia. Pada pemeriksaan dual task peningkatan yang signifikan pada perlakuan sebelum dan sesudah pelatihan. Dual Task Test mewakili konsentrasi, atensi, kemampuan cognitive berupa menghitung angka. Pada pengukuran ini pasien diminta untuk berjalan sambil berhitung mundur dari angka $100-7$ dan seterusnya $(93,86,79,72 \ldots)$, dari pemeriksaan ini apabila lansia saat memikirkan hitungan aritmatik berjalan sangat lambat dari biasanya atau berhenti sejenak atau berhenti berjalan sama sekali, maka lansia tersebut mempunyai resiko jatuh yang tinggi. Pada penelitian ini dapat disimpulkan bahwa ke dua pelatihan yaitu $\mathrm{Ai}$ Chi dan Tai Chi memberikan manfaat yang sama dalam meningkatkan kapasitas fisik lansia, peningkatan atensi, konsentrasi, peningkatan cognitive terkait cognitive motor dual task dan juga yang paling utama adalah menurunkan resiko jatuh.

Hasil penelitian ini menunjukan bahwa tidak ada perbedaan bermakna antara kedua pelatihan, sebagaimana dijelaskan bahwa pelatihan $\mathrm{Ai} C h \mathrm{i}$ mempunyai prinsip yang sama dengan Tai Chi dimana media latihannya yang berbeda $^{25}$, dapat disimpulkan juga bahwa tidak ada perbedaan pengaruh antara media pelatihan Ai Chi di air dan media pelatihan Tai Chi di darat pada penelitian ini. 


\section{KETERBATASAN PENELITIAN}

Adapun keterbatasan dalam penelitian ini adalah bahwa peneliti tidak dapat mengontrol aktifitas sampel yang dapat mempengaruhi hasil penelitian.

\section{SIMPULAN}

1. Pelatihan Tai Chi meningkatkan performa dual task pada lansia.

2. Pelatihan $A i C h i$ meningkatkan performa dual task pada lansia.

3. Pelatihan Tai Chi dan pelatihan $\mathrm{Ai} C h i$ mempunyai efek yang sama dalam meningkatkan performa dual task pada lansia.

\section{DAFTAR PUSTAKA}

1. Muir SW. 2012. The role of cognitive impairment in fall risk among older adults: a systematic review and meta-analysis. doi: 10.1093/ageing/afs012.

2. Holtzer R, Friedman R, Lipton RB, Katz M, Xue X, Verghese J. 2007. The relationship between specific cognitive functions and falls in aging. Neuropsychology. p. 540-8.

3. Alexander, N. B., \& Hausdorff, J. M. 2008. Guest Editorial: Linking Thinking, Walking, and Falling. The Journals of Gerontology Series A: Biological Sciences and Medical Sciences, 63(12), 1325-1328. doi:10.1093/gerona/63.12.1325.

4. Verghese J, Kuslansky G, Holtzer R, Katz M, Xue X, Buschke H, Pahor M. 2007. Walking while talking: effect of task prioritization in the elderly. Archives of Physical Medicine and Rehabilitation. p.50-3.

5. Chan RC, Shum D, Toulopoulou T, et al. 2008. Assessment of executive functions: Review of instruments and identification of critical issues. Arch Clin Neuropsychol. 23:201-216. [PubMed: 18096360]

6. Hausdorff JM, Buchman AS. 2013. What links gait speed and MCI with dementia? A fresh look at the association between motor and cognitive function. $J$ Gerontol A Biol Sci Med Sci. 68:409-411. [PubMed: 23401565]
7. Matthews MM, Williams HG. 2008. Can Tai chi enhance cognitive vitality? A preliminary study of cognitive executive control in older adults after A Tai chi intervention. JSC Med Assoc. 104:255-257.

8. Hall CD, Miszko T, Wolf SL. 2009. Effects of Tai Chi intervention on dual-task ability in older adults: a pilot study. Arch Phys Med Rehabil. p. 525-529.

9. Fong SM, Ng GY. 2006. The effects on sensorimotor performance and balance with Tai Chi training. Arch Phys Med Rehabil. p. 82-87.

10. Wayne PM, Fuerst ML. 2013.The Harvard Medical School Guide To Tai Chi, Shambhala Publications Inc. United States of America.

11. Erickson KI, Voss MW, Prakash RS, et al. 2011. Exercise training increases size of hippocampus and improves memory. Proc Natl Acad Sci U S A. 108:3017-3022. [PubMed: 21282661]

12. Fang $\mathrm{ZH}$, Lee $\mathrm{CH}$, Seo MK, et al. 2013. Effect of treadmill exercise on the BDNFmediated pathway in the hippocampus of stressed rats. Neurosci Res.

13. Voelcker-Rehage C, Godde B, Staudinger UM. 2011. Cardiovascular and coordination training differentially improve cognitive performance and neural processing in older adults. Front Hum Neurosci. 5:26. [PubMed: 21441997]

14. Herdener M, Esposito F, di Salle F, et al. 2010, Musical training induces functional plasticity in human hippocampus. $J$ Neurosci.; 30:1377-1384. [PubMed: 20107063]

15. Driemeyer J, Boyke J, Gaser C, et al. 2008. Changes in gray matter induced by learning--revisited. PloS One. 3:e2669. [PubMed: 18648501]

16. Hufner K, Binetti C, Hamilton DA, et al. 2011. Structural and functional plasticity of the hippocampal formation in professional dancers and slackliners. Hippocampus. 21:855-865. [PubMed: 20572197]

17. Tsang WW, Kwok JC, Hui-Chan CW. 2013. Effects of aging and tai chi on a fingerpointing task with a choice paradigm. Evidence-based Complementary and 
Alternative Medicine : eCAM: 653437. [PubMed: 23476699]

18. Wang C, Bannuru R, Ramel J, et al. 2010. Tai Chi on psychological well-being: Systematic review and meta-analysis. $B M C$ Complement Altern Med. 10:23. [PubMed: 20492638]

19. Lupien SJ, de Leon M, de Santi S, et al. 1998. Cortisol levels during human aging predict hippocampal atrophy and memory deficits. Nat Neurosci.; 1:69-73. [PubMed: 10195112]

20. Chiesa A, Calati R, Serretti A. 2011. Does mindfulness training improve cognitive abilities? A systematic review of neuropsychological findings. Clin Psychol Rev. 31:449-464. [PubMed: 21183265]

21. Verghese J, Lipton RB, Katz MJ, et al. 2003. Leisure activities and the risk of dementia in the elderly. $N$ Engl $J$ Med.; 348:2508-2516. [PubMed: 12815136]

22. Turana. 2013. Stimulasi Otak pada Kelompok Lansia di Komunitas. Buletin Lansia. p.23-24.

23. Lord, S. R., Matters, B., St George, R., Thomas, M., Bindon, J., Chan, D. K., Collings, A., \& Haren, L. 2006. The effects of water exercise on physical functioning in older people. Australasian Journal of Ageing, 25(1), 36-41.

24. Bielak, A.A. 2010. How can we not 'lose it' if we still don't understand how to 'use it'? Unanswered questions about the influence of activity participation on cognitive performance in older age-a mini-review. Gerontology, 56, 507-519. PubMed doi:10.1159/000264918

25. Teixeira R, PérezL, Lambeck J, Neto F. 2011. The influence of Ai Chi on balance and fear falling in older adults: a randomized clinical trial. Physiotherapy: 97 Supl: eS18-eS1415 